\title{
Teachers' Teaching Reading Strategies at Public Elementary Schools in Haripur District
}

Asad Ur Rehman ${ }^{1}$, Kifyat Khan ${ }^{1}$, Ajila Almas ${ }^{1}$, Maslawati Mohamad ${ }^{2 *}$, Nurul Huda Ismail $^{2}$

${ }^{1}$ University of Haripur, Khyber Pakhtunkhwa, Pakistan

${ }^{2}$ Faculty of Education, Universiti Kebangsaan Malaysia, Bangi, Malaysia

\section{ABSTRACT}

The growing importance of English as an international language globally demands the students in Pakistan to be proficient in English especially reading skills. Thus, the objective of the study was to identify which reading strategies were taught by the English teachers to elementary pupils. In order to achieve the research objective, quantitative research design was employed in this study. Data were collected through random sampling of 100 teachers from 50 public schools which offer English as a subject using a set of questionnaires. The data were analysed using SPSS. The data are presented in percentages and frequency. The major findings indicate that the majority of the teachers have many problems in teaching English reading strategies to elementary students. It is hoped that the findings could help the education department officers in developing a suitable module to conduct training for elementary English teachers. Such measure is vital in order to improve the teaching capabilities of the English teachers in teaching reading strategies as to enhance the pupils' reading comprehension.

Keywords:

Teaching Reading, Elementary Level, Reading Strategies, English Teachers

\section{Introduction}

Globally, English language is known as an international language especially for business, and academic purposes. Students all over the world should have the mastery of English in order to read and comprehend references which are mainly written in English. This is the main reason that a large number of students learn English language across the world (Alsagoff, McKay, Hu, \& Renandya, 2012). This is because English language is used as a medium of instruction all over the world (Rusciolelli, 1995). English teachers need to know what are the reading strategies needed employed by the students especially in English as a Second Language (ESL) context in which reading in a foreign language is even more demanding (Maslawati et al., 2015). Therefore, studies need to be conducted on the ESL English teachers' teaching approaches in teaching reading strategies to the students. The findings of such studies could be used for the relevant authority to conduct effective future training in order for them to become more effective English teachers. Hence, this study was embarked. The objective of this study was to identify the reading strategies taught by English teachers in the teaching of reading at elementary schools in Haripur, Khyber Pakhtunkhwa, Pakistan. By identifying the reading strategies taught by the elementary English school teachers, the findings could enlighten the education department officers in designing better module for English teacher training. It is hoped that when English teachers are trained with current developed module, they could equip their pupils with better reading 
strategies which resulted the pupils to become better readers of English materials. By equipping the pupils with these reading strategies, they could become independent readers with little assistance from the teacher (Maslawati et al., 2015).

\section{Literature Review}

Definitions of Reading Strategies

According to Barron (2017), reading strategies are the readers' mental procedures to accomplish a reading task. They stated that reading strategies are chains of actions reader practices in order to make meaning in their reading process. Brevik and Gunnulfsen (2013) defined reading strategies as procedures used by pupils to improve their reading comprehension. They further added that reading comprehension can be achieved if effective reading strategies are well-employed by the students. Reading strategies comprise of skimming, scanning and inferring to the core conceptualized ones such as stimulating schemata, identifying text structure, using mental images, envisaging, asking questions, monitoring comprehension, and assessing strategy used (Carrell, 1989; Maslawati et al., 2015). These strategies then are categorized into three stages which are pre-reading strategies, while-reading and post-reading strategies.

The Benefits of Reading Strategies to be Taught to Elementary Pupils

Reading in English as a second language (ESL) has been seriously emphasized in conventional L2 teaching, hence it is important for teachers to teach reading strategies to the pupils so that they can equip themselves in order to be able to explain what they have read, relate their reading comprehension of the reading materials to their schemata and evaluate the information (Paris, 1991). Teachers also need to develop pupils' personal cognitive tools or strategies which are essential for the pupils to enhance their attention in reading, and prolong their memory. The teachers need to teach the pupils on how to use these personal cognitive tools and reading strategies selectively and flexibly. When the pupils employ appropriate reading strategies, their reading comprehension and learning performance could be improved (Paris, 1991). Many other scholars also support Paris and his colleagues' perception. Roe, Smith and Burns (2011) claimed that the primary objective of teaching reading strategies to pupils is to enable them to apply a good repertoire of reading strategies effectively. The following subsections are detailed explanation of the reading strategies. These strategies are divided into three stages 1 ) pre-reading 2) while reading 3 ) post reading.

Pre-reading Reading Strategies

During pre-reading reading strategy, a teacher teaches pupils to find out what they should expect and learn from their reading. At this stage, pupils will be able to grasp the gist and concept portrayed in the reading material. This stage is important as it will help the pupils to develop and stimulate their prior information. In pre-reading stage, there are a few strategies that could be taught to the students. These strategies are: 1) previewing text, 2) guessing meaning, 3) using prior knowledge 4) skimming 5) scanning and 6) making predictions.

1) Previewing text

Previewing is among the first strategies taught to students whereby it means to activate the prior-knowledge about the reading material. Teachers teach students to do a simple check on the reading material such as read the synopsis, quick catch up on the table of contents or simply preview the text by looking at the title, the name of the author and the sub-headings. The purpose of this strategy is to generate interest and encourage active reading among the students.

2) Guessing meaning

During pre-reading reading strategies, teachers also teach the learners to guess the meaning. It could be to guess the meaning of the title/topic. 
3) Using prior knowledge

Using prior-knowledge is the strategy whereby students were taught to share ideas of their existing knowledge and relate it to the topic of the reading material. Priorknowledge is important as they will be able to relate the lesson with their everyday life.

\section{4) Skimming}

Skimming refers to a strategy employed by a reader when attempting to find some specific information or answers to comprehension questions, or when one reads in order to find some details in the text. Very often it is unnecessary and timeconsuming for a pupil to read in detail every word in a text.

5) Scanning

Artelt et al. (2001) mentioned that scanning refers to the strategy employed by a reader when the purpose of reading is to get an overview of the text. They further added that pupils should be taught skimming and scanning, not only reading for detailed information.

6) Making predictions

In making prediction strategy, students were taught to predict the content of the reading material. They can predict and assume what they are going to learn from the topic or the title of the reading material as well as predicting the outcome of the lesson.

While-reading Reading Strategies

One of the most important strategies in reading is while-reading reading strategies. These strategies should be used in combination with other strategies like: paying attention to text structure and organization, guessing meaning of unknown words and phrases. The pupils should be taught to use all the strategies, but should also be able to identify when it is appropriate to use one strategy or the other (Maslawati et al., 2015). Teaching pupils with reading strategies should enable them to know which strategies to employ, when and how to use them. Consequently, the students will be more engaged in the reading material and gain much important information from the reading material. This strategy would enable the pupils to achieve the learning objectives from the reading material. While-reading reading strategies can be divided into two categories which are 1 ) cognitive reading strategies and 2 ) meta-cognitive reading strategies.

1) Cognitive reading strategies

It is a conscious process whereby the students must be aware of the reading process itself (Brevik \& Gunnulfsen, 2013). These strategies are analyzing, highlighting, taking notes, identifying main ideas and drawing inferences (Roe, Smith, \& Burns, 2011; Brevik \& Gunnulfsen, 2013). These reading strategies have been frequently discovered by many researchers when they conducted studies on identifying students' reading strategies. Many researchers discovered that these three cognitive reading strategies are the ones that are most beneficial for the pupils, and could easily be taught to them (Brevik \& Gunnulfsen, 2013).

2) Meta-cognitive reading strategies

Meta-cognitive or control reading strategies could be used by the pupils to control, and check whether they have comprehended a text (Roe, Smith, \& Burns, 2011; Brevik \& Gunnulfsen, 2013). Good readers utilize these strategies to check their comprehension level when reading a text (Paris, 1991). They would pause their reading, read slowly or repeat the sentence to evaluate if there are any concepts they do not understand or they need to figure out in order to understand the text as a whole. In other words, they evaluate their own reading process. They constantly evaluate whether the reading strategies they use are appropriate for the task/s or problem/s they are trying to solve (Brevik \& Gunnulfsen, 2013) by generating questions. These strategies could also be used after they have completed reading a text. 
Paris (1991) added that the pupils should stop after having read a paragraph or two, and conduct self-evaluation if they could remember the important information in the paragraph(s). A problem that might arise here is that some pupils may not know what is important and what is less important, especially pupils with low reading ability.

Post reading strategies

The other reading strategy taught by the teachers is post-reading reading strategies. This strategy is important to help pupils use their acquired knowledge from the reading materials and integrate the knowledge with other language skills such as listening, speaking and writing. In this strategy, pupils will be more likely to achieve the learning objectives, hence, they would be able to extract and interpret the important information from the reading material and make use of the information for other activities or lessons. Examples of post-reading reading strategy are 1) using visual representatives, 2) consulting relevant source/s, 3) paraphrasing and 4) criticizing the text.

1) Using visual representatives

In this strategy, students were taught to transform the information they gather from the reading material into visualization. Students can use mind-mapping, draw or doodle and using other visual representation such as videos, photos or scrapbooking.

2) Consulting relevant source/s

Consulting relevant source/s is the strategy whereby students are taught to find additional information from other sources such as interviews, documentaries or from other books/articles. This strategy helps students to have better understanding about the topic discussed in the reading material.

3) Paraphrasing

Next strategy in the post-reading reading strategy is paraphrasing. This is the strategy whereby students are taught to transfer and elaborate their understanding and information gathered from the reading material into simpler words that they understand.

4) Criticizing the text

Criticizing the text is the strategy which students were taught to give comments and share their opinions about the reading material. Students could criticize the text in terms of content, the writing technicalities and also criticized by comparing reading material they read with other reading materials of the same topic.

\section{Methodology}

The research design employed in this study was quantitative approach. The data were collected using a set of questionnaire. The data are presented in the form of tables.

Population

There are 100 hundred Elementary schools in Haripur district. However, the researchers only selected fifty public Elementary schools as English language is taught as a compulsory subject at these schools. The English teachers of these selected schools were the target population of this study.

Sample

Random sampling technique was employed. A total of 100 teachers were selected as the sample. These teachers were taken from the 50 selected schools as mentioned above. Two teachers from each sampled school were selected.

Research Instrument

The research instrument utilized in this study is a questionnaire. The total number of items is 18. All the items are in the form of statement. The items use five-point Likert type scale whereby 1) Never, 2) Rarely, 3) Sometimes, 4) Very Often, 5) 
Always. The items are related to the pupils' reading strategies that are being taught by the English teachers. One of the researchers visited all the sampled schools to distribute and collect the questionnaire. The items in the questionnaire were constructed based on the literature review that includes research papers, theses, books and websites. The items were checked and validated by experts including experienced teachers, and university lecturers. The validity was established in this manner.

The validated items were piloted to 10 elementary English teachers from Haripur district. These teachers were not included in the sampled schools. The data from the questionnaire were later collected and analyzed. After the pilot study, some items were deleted and some items were modified. Some items were refined in order to retrieve more accurate answers from the respondents. The final version of the questionnaire consists of 18 items.

\section{Analysis and Interpretation}

The data were analysed using Statistical Package for Social Sciences (SPSS). The data were analysed and presented using frequency and percentages. The data obtained were then tabulated and interpreted in order to achieve the research objective. The researchers divided the tables into a few subsections accordingly; Table 1) Pre-Reading Reading Strategies, Table 2) While-Reading Reading Strategies, Table 3) Post-Reading Reading Strategies.

Table 1 provides the data on pre-reading reading strategies obtained from the questionnaire. The finding indicates that there were about $55 \%$ of teachers who are always taught previewing-text strategy while the other $23 \%$ are very often taught the strategy and only $6 \%$ of the teachers never taught the strategies while

Table 1. Pre-reading reading strategies taught by the teacher.

Table 2. While-reading reading strategies taught by the teacher.

Table 3. Post-reading reading strategies.

the other $7 \%$ were rarely and $9 \%$ were sometimes taught the previewing the text strategy. Furthermore, from the findings it can be seen that $17 \%$ of teachers never taught guessing meaning strategy, $11 \%$ of them were rarely taught, $19 \%$ of the teachers sometimes taught whereby $25 \%$ and $28 \%$ of the teachers were respectively very often and always taught the guessing meaning strategy. According to the findings as well, $64.4 \%$ of the teachers taught using prior-knowledge strategy as one of the strategies taught in pre-reading reading strategy. In this strategy, $14.1 \%$ of the teachers were also very often taught the strategy while the other $17.2 \%$ sometimes taught, $3 \%$ were rarely taught and about only $1 \%$ of the teachers were never taught this strategy.

The statement also shows that $47 \%$ of the teachers never taught skimming strategy, $11 \%$ rarely taught, $18 \%$ sometimes taught, $18 \%$ were very often taught and only $6 \%$ were always taught this strategy. The data also shows that from the findings, $31 \%$ of the teachers never taught scanning while $17 \%$ rarely taught, $16 \%$ were sometimes taught, $27 \%$ very often taught yet only $9 \%$ were always taught scanning strategy. As for making predictions during this pre-reading reading strategy, it can be seen that $16 \%$ of the teachers were never taught the strategy, 
$20 \%$ of rarely taught, $20 \%$ of sometimes taught and that makes $16 \%$ of them very often taught and $28 \%$ of them were always taught the strategy.

Moving on, Table 2 provides further elaboration on the next part of reading strategies which is while-reading reading strategies taught by the English teachers. The data shows that $50 \%$ of the teachers taught analysing strategy during whilereading, $15 \%$ of them very often taught while $21 \%$ of them sometimes taught and only $7 \%$ of the teachers rarely taught and $7 \%$ never taught analysing strategy. From the data, it is clear that $55 \%$ of the teachers always taught highlighting strategy during while-reading, $17 \%$ very often taught, $18 \%$ sometimes taught, $6 \%$ rarely taught and only $4 \%$ never taught the pupils highlighting strategy during while-reading. As for taking notes strategy, the findings were spread evenly with $28 \%$ of the teachers were always taught, $30 \%$ very often, $22 \%$ and $12 \%$ and $8 \%$ both for rarely and never taught of the strategy.

Meanwhile, as for identifying main ideas, $65 \%$ of the teachers were always taught of the strategy, $20 \%$ of them very often taught and that makes $7 \%$ of the teachers sometimes taught and 3\% and 5\% for rarely and never taught the strategy. As for paying attention $57 \%$ always taught this strategy during while-reading reading strategy, $27 \%$ very often taught and only $7 \%$ were sometimes taught, $2 \%$ rarely taught and $7 \%$ were never taught of the paying attention strategy to the pupils during while-reading. Last but not least, the other strategy taught by the students during while-reading reading strategy is drawing inference. From the data, it was found that $41 \%$ of the teachers were always taught this strategy, $21 \%$ of them were very often taught, $8 \%$ sometimes taught, $11 \%$ rarely taught and only $9 \%$ were never taught drawing inference strategy.

Table 3 shows the results of the questionnaires asked regarding post-reading reading strategy taught by the teachers. It was found out that from the data, $22 \%$ of the teachers always taught the conforming and disconfirming strategy while $24 \%$ of the teachers very often taught the strategy and it makes the other $29 \%$ of the teachers sometimes taught, $13 \%$ rarely taught and $12 \%$ never taught of the strategy. As for consulting outside source, $25 \%$ of the teachers always taught this strategy, while $26 \%$ of them were very often taught, $17 \%$ sometimes taught the strategy and the rest of $25 \%$ rarely taught and only $7 \%$ of them never taught the strategy. From the data, it can also be seen that there were only $12 \%$ of the teachers never taught paraphrasing, $15 \%$ rarely taught while $10 \%$ sometimes taught the strategy. However, there were also $20 \%$ of very often taught and $43 \%$ were always taught paraphrasing as for post-reading reading strategy.

Meanwhile, from the findings it can also be seen that $48 \%$ of the teacher always taught of the generating question strategy during post-reading, $28 \%$ of the teachers very often taught, $12 \%$ sometimes taught and both $6 \%$ for rarely and never taught. Lastly, $16 \%$ of the teachers stated that they never taught criticizing the reading material, and $20 \%$ of the rarely taught the strategy. Yet, the other $20 \%$ stated sometimes they taught the strategy of criticizing the reading material while $16 \%$ of them sometimes taught and $28 \%$ of them always taught that strategy during postreading.

\section{Discussion and Conclusion}

As a conclusion, it could be concluded that English teachers in Haripur district taught all the reading strategies mentioned according to their favours of choice. As for the pre-reading reading strategy, it could be derived that teachers preferred to teach previewing text and using prior-knowledge strategy compared to the other reading strategies. The researchers of this study found that more than half of the teachers taught the pupils to use prior knowledge in reading strategy which is parallel to Afflerbach's belief (1990). He stated that relating to one's prior-knowledge is one 
of the most useful strategies in reading strategy as it helps pupils to have better comprehension towards the reading material for the elementary pupils. This is quite odd as there were many previous studies mentioned that skimming and scanning

are amongst the most favourable and popular strategies taught by the teachers. Rusciolelli (1995) mentioned that skimming is the most useful strategy in reading skills and Salataci and Akyel (2002) stated that in comparison to skimming, scanning is the most frequently used strategy in reading skills. As for making predictions strategy it was unlikely to be taught by the teachers according to the findings of this study yet it is contradicting to Bernhardt (2010) and Afflerbach (1990). These researchers highlighted that making predictions is one of the most frequently taught and used reading strategies.

On the other hand, as for the while-reading reading strategies, all the strategies were fairly taught by the elementary English teachers. All the strategies involved in this while-reading stage such as analysing, highlighting, taking notes, generating questions, identifying main ideas, and drawing inference were taught well by the teachers. This might be due to the while-reading stage is the most crucial stage of reading whereby pupils have to pay attention during this stage of reading as to achieve the learning objectives. However, from the data, the researchers could conclude that teachers favour to teach identifying main ideas compared to other reading strategies.

Furthermore, the findings from this study indicate that almost half of the teachers taught the pupils to generate questions from the reading material as one of the reading strategies. This finding then supported by the previous study conducted by Rosenshine, Meister and Chapmen (1996) whereby they pointed out that generating questions as one of the useful strategies in reading as it helps pupils to comprehend the reading material. Strategies such as using visual representation are among the most favourable reading strategies to be taught as the post-reading reading strategies. This is supported by the study done by Nur Alia and Maslawati (2019) whereby it stated that using visual representation is the most frequent strategy used in reading skills.

Generally, the strategies should preferably be used in combination with other reading strategies. The pupils should be able to use all of the reading strategies. They should also be able to identify when it is appropriate to use one or the other strategies. This is parallel to some renowned researchers' belief: "Personal cognitive tools are called strategies that can be used selectively and flexibly" (Paris, 1991). The main goal with teaching reading strategies should be to make the pupils capable enough in their use of reading strategies so that they are able to know which strategies to employ and when and how to use them.

\section{Recommendations}

It is recommended that the students must be given more awareness about the strategies they need to use in order to fully understand the reading materials. Furthermore, the concerned Higher Education Authorities may conduct training workshops for the teachers teaching at elementary level' to improve their teaching skills. Moreover, the ministry of education under its supervision should launch seminars and workshops for the elementary level teachers with better incentives for them. Likewise, the highlighted problems of this research should be further researched. The future researchers may investigate the further problematic areas associated with the teaching of reading skills to students at elementary level. Furthermore, the curriculum developers are recommended to consider the results of this study while framing the structure of textbooks at elementary level. It is suggested that the policy makers may review their recruitment policies so that only those teachers should be recruited who possess professional qualification with 
English. Last but not the least, the RITEs and PITEs are recommended to place the reading strategies in the various related disciplines.

\section{Conflicts of Interest}

The authors declare no conflicts of interest regarding the publication of this paper.

\section{Cite this paper}

Rehman, A. U., Khan, K., Almas, A., Mohamad, M., \& Ismail, N. H. (2020). Teachers' Teaching Reading Strategies at Public Elementary Schools in Haripur District. Creative Education, 11, 468-478. https://doi.org/10.4236/ce.2020.114034

\section{References}

Siayah, Syarofis; \& Setiawan, Adib Rifqi. (2020, April 13). A Brief Explanation of Science Education. EdArXiv. DOI: https://doi.org/10.35542/osf.io/2evn3

Siayah, Syarofis; \& Setiawan, Adib Rifqi. (2020, April 13). A Brief Explanation of Science Education. Thesis Commons. DOI: https://doi.org/10.31237/osf.io/wkvsn

Setiawan, Adib Rifai; \& Ilmiyah, Surotul. (2020, April 13). Multiple Intelligences Based on Neuroscience. Thesis Commons. DOI: https://doi.org/10.31237/osf.io/e9fyu

Setiawan, Adib Rifqi; \& Ilmiyah, Surotul. (2020, April 13). Kecerdasan Majemuk Berdasarkan Neurosains. EdArXiv. DOI: https://doi.org/10.35542/osf.io/rj2fe

Setiawan, Adib Rifqi. (2020, April 9). Islamic Education in Southeast Asia. EdArXiv. DOI: https://doi.org/10.35542/osf.io/dnjqv

Ilmiyah, Surotul; \& Setiawan, Adib Rifqi. (2020, April 7). Students' Worksheet for Distance Learning Based on Scientific Literacy in the Topic Coronavirus Disease 2019 (COVID-19). Thesis Commons. DOI: https://doi.org/10.31237/osf.io/fpg4j

Ilmiyah, Surotul; \& Setiawan, Adib Rifqi. (2020, April 7). Students' Worksheet for Distance Learning Based on Scientific Literacy in the Topic Coronavirus Disease 2019 (COVID-19). EdArXiv. DOI: https://doi.org/10.35542/osf.io/wyz5v

Setiawan, Adib Rifqi; \& Ilmiyah, Surotul. (2020, April 7). Lembar Kegiatan Siswa untuk Pembelajaran Jarak Jauh Berdasarkan Literasi Saintifik pada Topik Penyakit Coronavirus 2019 (COVID-19). EdArXiv. DOI: https://doi.org/10.35542/osf.io/h4632

Setiawan, Adib Rifqi. (2020, April 2). Desain Pembelajaran untuk Membimbing Siswa Sekolah Dasar dalam Memperoleh Literasi Saintifik. EdArXiv. DOI: https://doi.org/10.35542/osf.io/u59f8

Velasufah, Whasfi; \& Setiawan, Adib Rifqi. (2020, April 13). Nilai Pesantren Sebagai Dasar Pendidikan Karakter. Thesis Commons. DOI: https://doi.org/10.31237/osf.io/hq6kz

Setiawan, Adib Rifqi. (2020, April 9). Islamic Education in Southeast Asia. Thesis Commons. DOI: https://doi.org/10.31237/osf.io/e794d

Setiawan, Adib Rifqi. (2020, April 2). What is the Best Way to Analyze Pre-Post Data?. EdArXiv. DOI: https://doi.org/10.35542/osf.io/h4e6q

Setiawan, Adib Rifqi. (2020, April 4). Grace Natalie Louisa. SocArXiv. DOI: https://doi.org/10.31235/osf.io/zwf6g

Setiawan, Adib Rifqi. (2020, April 3). Sharifah Halimah Alaydrus : a female preachers for our time. SocArXiv. DOI: https://doi.org/10.31235/osf.io/zb8qe

Setiawan, Adib Rifqi. (2020, April 1). Syarifah Halimah Alaydrus. Thesis Commons. DOI: https://doi.org/10.31237/osf.io/xbmcs 
Setiawan, Adib Rifqi. (2020, April 13). Commodification of the Sexuality in Kim Kardashian's Instagram Posts. Thesis Commons. URL: https://thesiscommons.org/mf7nw/

Setiawan, Adib Rifqi. (2020, April 5). The Arrogant One. Thesis Commons. DOI: https://doi.org/10.31237/osf.io/8nmku

Setiawan, Adib Rifqi. (2020, April 4). Grace Natalie Louisa. Thesis Commons. DOI: https://doi.org/10.31237/osf.io/u3mxv

Setiawan, Adib Rifqi. (2020, April 2). JUPE My Uncut Story. Open Science Framework (OSF). DOI: https://doi.org/10.31219/osf.io/qdxga

Setiawan, Adib Rifqi. (2020, April 1). Sharifah Halimah Alaydrus. Thesis Commons. DOI: https://doi.org/10.31237/osf.io/fp79c

Setiawan, Adib Rifqi. (2020, April 13). مبادئ اللغة العربية. Thesis Commons. DOI: https://doi.org/10.31237/osf.io/2gvjf

Siayah, Syarofis; \& Setiawan, Adib Rifqi. (2020, April 13). A Brief Explanation of Science Education. EdArXiv. DOI: https://doi.org/10.35542/osf.io/2evn3

Siayah, Syarofis; \& Setiawan, Adib Rifqi. (2020, April 13). A Brief Explanation of Science Education. Thesis Commons. DOI: https://doi.org/10.31237/osf.io/wkvsn

Setiawan, Adib Rifai; \& Ilmiyah, Surotul. (2020, April 13). Multiple Intelligences Based on Neuroscience. Thesis Commons. DOI: https://doi.org/10.31237/osf.io/e9fyu

Setiawan, Adib Rifqi; \& Ilmiyah, Surotul. (2020, April 13). Kecerdasan Majemuk Berdasarkan Neurosains. EdArXiv. DOI: https://doi.org/10.35542/osf.io/rj2fe

Setiawan, Adib Rifqi. (2020, April 9). Islamic Education in Southeast Asia. EdArXiv. DOI: https://doi.org/10.35542/osf.io/dnjqv

Ilmiyah, Surotul; \& Setiawan, Adib Rifqi. (2020, April 7). Students' Worksheet for Distance Learning Based on Scientific Literacy in the Topic Coronavirus Disease 2019 (COVID-19). Thesis Commons. DOI: https://doi.org/10.31237/osf.io/fpg4j

Ilmiyah, Surotul; \& Setiawan, Adib Rifqi. (2020, April 7). Students' Worksheet for Distance Learning Based on Scientific Literacy in the Topic Coronavirus Disease 2019 (COVID-19). EdArXiv. DOI: https://doi.org/10.35542/osf.io/wyz5v

Setiawan, Adib Rifqi; \& Ilmiyah, Surotul. (2020, April 7). Lembar Kegiatan Siswa untuk Pembelajaran Jarak Jauh Berdasarkan Literasi Saintifik pada Topik Penyakit Coronavirus 2019 (COVID-19). EdArXiv. DOI: https://doi.org/10.35542/osf.io/h4632

Setiawan, Adib Rifqi. (2020, April 2). Desain Pembelajaran untuk Membimbing Siswa Sekolah Dasar dalam Memperoleh Literasi Saintifik. EdArXiv. DOI: https://doi.org/10.35542/osf.io/u59f8

Velasufah, Whasfi; \& Setiawan, Adib Rifqi. (2020, April 13). Nilai Pesantren Sebagai Dasar Pendidikan Karakter. Thesis Commons. DOI: https://doi.org/10.31237/osf.io/hq6kz

Setiawan, Adib Rifqi. (2020, April 9). Islamic Education in Southeast Asia. Thesis Commons. DOI: https://doi.org/10.31237/osf.io/e794d

Setiawan, Adib Rifqi. (2020, April 2). What is the Best Way to Analyze Pre-Post Data?. EdArXiv. DOI: https://doi.org/10.35542/osf.io/h4e6q

Setiawan, Adib Rifqi. (2020, April 4). Grace Natalie Louisa. SocArXiv. DOI: https://doi.org/10.31235/osf.io/zwf6g

Setiawan, Adib Rifqi. (2020, April 3). Sharifah Halimah Alaydrus : a female preachers for our time. SocArXiv. DOI: https://doi.org/10.31235/osf.io/zb8qe

Setiawan, Adib Rifqi. (2020, April 1). Syarifah Halimah Alaydrus. Thesis Commons. DOI: https://doi.org/10.31237/osf.io/xbmcs

Setiawan, Adib Rifqi. (2020, April 13). Commodification of the Sexuality in Kim Kardashian's Instagram Posts. Thesis Commons. URL: https://thesiscommons.org/mf7nw/

Setiawan, Adib Rifqi. (2020, April 5). The Arrogant One. Thesis Commons. DOI: https://doi.org/10.31237/osf.io/8nmku 
Setiawan, Adib Rifqi. (2020, April 4). Grace Natalie Louisa. Thesis Commons. DOI: https://doi.org/10.31237/osf.io/u3mxv

Setiawan, Adib Rifqi. (2020, April 2). JUPE My Uncut Story. Open Science Framework (OSF). DOI: https://doi.org/10.31219/osf.io/qdxga

Setiawan, Adib Rifqi. (2020, April 1). Sharifah Halimah Alaydrus. Thesis Commons. DOI: https://doi.org/10.31237/osf.io/fp79c

Setiawan, Adib Rifqi. (2020, April 13). مبادئ اللغة العربية. Thesis Commons. DOI: https://doi.org/10.31237/osf.io/2gvjf

Siayah, Syarofis; \& Setiawan, Adib Rifqi. (2020, April 13). A Brief Explanation of Science Education. EdArXiv. DOI: https://doi.org/10.35542/osf.io/2evn3

Siayah, Syarofis; \& Setiawan, Adib Rifqi. (2020, April 13). A Brief Explanation of Science Education. Thesis Commons. DOI: https://doi.org/10.31237/osf.io/wkvsn

Setiawan, Adib Rifai; \& Ilmiyah, Surotul. (2020, April 13). Multiple Intelligences Based on Neuroscience. Thesis Commons. DOI: https://doi.org/10.31237/osf.io/e9fyu

Setiawan, Adib Rifai; \& Ilmiyah, Surotul. (2020, April 13). Kecerdasan Majemuk Berdasarkan Neurosains. EdArXiv. DOI: https://doi.org/10.35542/osf.io/rj2fe

Setiawan, Adib Rifqi. (2020, April 9). Islamic Education in Southeast Asia. EdArXiv. DOI: https://doi.org/10.35542/osf.io/dnjqv

Ilmiyah, Surotul; \& Setiawan, Adib Rifqi. (2020, April 7). Students' Worksheet for Distance Learning Based on Scientific Literacy in the Topic Coronavirus Disease 2019 (COVID-19). Thesis Commons. DOI: https://doi.org/10.31237/osf.io/fpg4j

Ilmiyah, Surotul; \& Setiawan, Adib Rifqi. (2020, April 7). Students' Worksheet for Distance Learning Based on Scientific Literacy in the Topic Coronavirus Disease 2019 (COVID-19). EdArXiv. DOI: https://doi.org/10.35542/osf.io/wyz5v

Setiawan, Adib Rifqi; \& Ilmiyah, Surotul. (2020, April 7). Lembar Kegiatan Siswa untuk Pembelajaran Jarak Jauh Berdasarkan Literasi Saintifik pada Topik Penyakit Coronavirus 2019 (COVID-19). EdArXiv. DOI: https://doi.org/10.35542/osf.io/h4632

Setiawan, Adib Rifqi. (2020, April 2). Desain Pembelajaran untuk Membimbing Siswa Sekolah Dasar dalam Memperoleh Literasi Saintifik. EdArXiv. DOI: https://doi.org/10.35542/osf.io/u59f8

Velasufah, Whasfi; \& Setiawan, Adib Rifqi. (2020, April 13). Nilai Pesantren Sebagai Dasar Pendidikan Karakter. Thesis Commons. DOI: https://doi.org/10.31237/osf.io/hq6kz

Setiawan, Adib Rifqi. (2020, April 9). Islamic Education in Southeast Asia. Thesis Commons. DOI: https://doi.org/10.31237/osf.io/e794d

Setiawan, Adib Rifqi. (2020, April 2). What is the Best Way to Analyze Pre-Post Data?. EdArXiv. DOI: https://doi.org/10.35542/osf.io/h4e6q

Setiawan, Adib Rifqi. (2020, April 4). Grace Natalie Louisa. SocArXiv. DOI: https://doi.org/10.31235/osf.io/zwf6g

Setiawan, Adib Rifqi. (2020, April 3). Sharifah Halimah Alaydrus : a female preachers for our time. SocArXiv. DOI: https://doi.org/10.31235/osf.io/zb8qe

Setiawan, Adib Rifqi. (2020, April 1). Syarifah Halimah Alaydrus. Thesis Commons. DOI: https://doi.org/10.31237/osf.io/xbmcs

Setiawan, Adib Rifqi. (2020, April 13). Commodification of the Sexuality in Kim Kardashian's Instagram Posts. Thesis Commons. URL: https://thesiscommons.org/mf7nw/

Setiawan, Adib Rifqi. (2020, April 5). The Arrogant One. Thesis Commons. DOI: https://doi.org/10.31237/osf.io/8nmku

Setiawan, Adib Rifqi. (2020, April 4). Grace Natalie Louisa. Thesis Commons. DOI: https://doi.org/10.31237/osf.io/u3mxv

Setiawan, Adib Rifqi. (2020, April 2). JUPE My Uncut Story. Open Science Framework (OSF). DOI: https://doi.org/10.31219/osf.io/qdxga 
Setiawan, Adib Rifqi. (2020, April 1). Sharifah Halimah Alaydrus. Thesis Commons. DOI: https://doi.org/10.31237/osf.io/fp79c

Setiawan, Adib Rifqi. (2020, April 13). مبادئ اللغة العربية. Thesis Commons. DOI: https://doi.org/10.31237/osf.io/2gvjf

Siayah, Syarofis; \& Setiawan, Adib Rifqi. (2020, April 13). A Brief Explanation of Science Education. EdArXiv. DOI: https://doi.org/10.35542/osf.io/2evn3

Siayah, Syarofis; \& Setiawan, Adib Rifqi. (2020, April 13). A Brief Explanation of Science Education. Thesis Commons. DOI: https://doi.org/10.31237/osf.io/wkvsn

Setiawan, Adib Rifai; \& Ilmiyah, Surotul. (2020, April 13). Multiple Intelligences Based on Neuroscience. Thesis Commons. DOI: https://doi.org/10.31237/osf.io/e9fyu

Setiawan, Adib Rifqi; \& Ilmiyah, Surotul. (2020, April 13). Kecerdasan Majemuk Berdasarkan Neurosains. EdArXiv. DOI: https://doi.org/10.35542/osf.io/rj2fe

Setiawan, Adib Rifqi. (2020, April 9). Islamic Education in Southeast Asia. EdArXiv. DOI: https://doi.org/10.35542/osf.io/dnjqv

Ilmiyah, Surotul; \& Setiawan, Adib Rifqi. (2020, April 7). Students' Worksheet for Distance Learning Based on Scientific Literacy in the Topic Coronavirus Disease 2019 (COVID-19). Thesis Commons. DOI: https://doi.org/10.31237/osf.io/fpg4j

Ilmiyah, Surotul; \& Setiawan, Adib Rifqi. (2020, April 7). Students' Worksheet for Distance Learning Based on Scientific Literacy in the Topic Coronavirus Disease 2019 (COVID-19). EdArXiv. DOI: https://doi.org/10.35542/osf.io/wyz5v

Setiawan, Adib Rifqi; \& Ilmiyah, Surotul. (2020, April 7). Lembar Kegiatan Siswa untuk Pembelajaran Jarak Jauh Berdasarkan Literasi Saintifik pada Topik Penyakit Coronavirus 2019 (COVID-19). EdArXiv. DOI: https://doi.org/10.35542/osf.io/h4632

Setiawan, Adib Rifqi. (2020, April 2). Desain Pembelajaran untuk Membimbing Siswa Sekolah Dasar dalam Memperoleh Literasi Saintifik. EdArXiv. DOI: https://doi.org/10.35542/osf.io/u59f8

Velasufah, Whasfi; \& Setiawan, Adib Rifqi. (2020, April 13). Nilai Pesantren Sebagai Dasar Pendidikan Karakter. Thesis Commons. DOI: https://doi.org/10.31237/osf.io/hq6kz

Setiawan, Adib Rifqi. (2020, April 9). Islamic Education in Southeast Asia. Thesis Commons. DOI: https://doi.org/10.31237/osf.io/e794d

Setiawan, Adib Rifqi. (2020, April 2). What is the Best Way to Analyze Pre-Post Data?. EdArXiv. DOI: https://doi.org/10.35542/osf.io/h4e6q

Setiawan, Adib Rifqi. (2020, April 4). Grace Natalie Louisa. SocArXiv. DOI: https://doi.org/10.31235/osf.io/zwf6g

Setiawan, Adib Rifqi. (2020, April 3). Sharifah Halimah Alaydrus : a female preachers for our time. SocArXiv. DOI: https://doi.org/10.31235/osf.io/zb8qe

Setiawan, Adib Rifqi. (2020, April 1). Syarifah Halimah Alaydrus. Thesis Commons. DOI: https://doi.org/10.31237/osf.io/xbmcs

Setiawan, Adib Rifqi. (2020, April 13). Commodification of the Sexuality in Kim Kardashian's Instagram Posts. Thesis Commons. URL: https://thesiscommons.org/mf7nw/

Setiawan, Adib Rifqi. (2020, April 5). The Arrogant One. Thesis Commons. DOI: https://doi.org/10.31237/osf.io/8nmku

Setiawan, Adib Rifqi. (2020, April 4). Grace Natalie Louisa. Thesis Commons. DOI: https://doi.org/10.31237/osf.io/u3mxv

Setiawan, Adib Rifqi. (2020, April 2). JUPE My Uncut Story. Open Science Framework (OSF). DOI: https://doi.org/10.31219/osf.io/qdxga

Setiawan, Adib Rifqi. (2020, April 1). Sharifah Halimah Alaydrus. Thesis Commons. DOI: https://doi.org/10.31237/osf.io/fp79c 
Setiawan, Adib Rifqi. (2020, April 13). مبادئ اللغة العربية. Thesis Commons. DOI: https://doi.org/10.31237/osf.io/2gvjf

Siayah, Syarofis; \& Setiawan, Adib Rifqi. (2020, April 13). A Brief Explanation of Science Education. EdArXiv. DOI: https://doi.org/10.35542/osf.io/2evn3

Siayah, Syarofis; \& Setiawan, Adib Rifqi. (2020, April 13). A Brief Explanation of Science Education. Thesis Commons. DOI: https://doi.org/10.31237/osf.io/wkvsn

Setiawan, Adib Rifai; \& Ilmiyah, Surotul. (2020, April 13). Multiple Intelligences Based on Neuroscience. Thesis Commons. DOI: https://doi.org/10.31237/osf.io/e9fyu

Setiawan, Adib Rifqi; \& Ilmiyah, Surotul. (2020, April 13). Kecerdasan Majemuk Berdasarkan Neurosains. EdArXiv. DOI: https://doi.org/10.35542/osf.io/rj2fe

Setiawan, Adib Rifqi. (2020, April 9). Islamic Education in Southeast Asia. EdArXiv. DOI: https://doi.org/10.35542/osf.io/dnjqv

Ilmiyah, Surotul; \& Setiawan, Adib Rifqi. (2020, April 7). Students' Worksheet for Distance Learning Based on Scientific Literacy in the Topic Coronavirus Disease 2019 (COVID-19). Thesis Commons. DOI: https://doi.org/10.31237/osf.io/fpg4j

Ilmiyah, Surotul; \& Setiawan, Adib Rifqi. (2020, April 7). Students' Worksheet for Distance Learning Based on Scientific Literacy in the Topic Coronavirus Disease 2019 (COVID-19). EdArXiv. DOI: https://doi.org/10.35542/osf.io/wyz5v

Setiawan, Adib Rifqi; \& Ilmiyah, Surotul. (2020, April 7). Lembar Kegiatan Siswa untuk Pembelajaran Jarak Jauh Berdasarkan Literasi Saintifik pada Topik Penyakit Coronavirus 2019 (COVID-19). EdArXiv. DOI: https://doi.org/10.35542/osf.io/h4632

Setiawan, Adib Rifqi. (2020, April 2). Desain Pembelajaran untuk Membimbing Siswa Sekolah Dasar dalam Memperoleh Literasi Saintifik. EdArXiv. DOI: https://doi.org/10.35542/osf.io/u59f8

Velasufah, Whasfi; \& Setiawan, Adib Rifqi. (2020, April 13). Nilai Pesantren Sebagai Dasar Pendidikan Karakter. Thesis Commons. DOI: https://doi.org/10.31237/osf.io/hq6kz

Setiawan, Adib Rifqi. (2020, April 9). Islamic Education in Southeast Asia. Thesis Commons. DOI: https://doi.org/10.31237/osf.io/e794d

Setiawan, Adib Rifqi. (2020, April 2). What is the Best Way to Analyze Pre-Post Data?. EdArXiv. DOI: https://doi.org/10.35542/osf.io/h4e6q

Setiawan, Adib Rifqi. (2020, April 4). Grace Natalie Louisa. SocArXiv. DOI: https://doi.org/10.31235/osf.io/zwf6g

Setiawan, Adib Rifqi. (2020, April 3). Sharifah Halimah Alaydrus : a female preachers for our time. SocArXiv. DOI: https://doi.org/10.31235/osf.io/zb8qe

Setiawan, Adib Rifqi. (2020, April 1). Syarifah Halimah Alaydrus. Thesis Commons. DOI: https://doi.org/10.31237/osf.io/xbmcs

Setiawan, Adib Rifqi. (2020, April 13). Commodification of the Sexuality in Kim Kardashian's Instagram Posts. Thesis Commons. URL: https://thesiscommons.org/mf7nw/

Setiawan, Adib Rifqi. (2020, April 5). The Arrogant One. Thesis Commons. DOI: https://doi.org/10.31237/osf.io/8nmku

Setiawan, Adib Rifqi. (2020, April 4). Grace Natalie Louisa. Thesis Commons. DOI: https://doi.org/10.31237/osf.io/u3mxv

Setiawan, Adib Rifqi. (2020, April 2). JUPE My Uncut Story. Open Science Framework (OSF). DOI: https://doi.org/10.31219/osf.io/qdxga

Setiawan, Adib Rifqi. (2020, April 1). Sharifah Halimah Alaydrus. Thesis Commons. DOI: https://doi.org/10.31237/osf.io/fp79c

Setiawan, Adib Rifqi. (2020, April 13). مبادئ اللغة العربية. Thesis Commons. DOI: https://doi.org/10.31237/osf.io/2gvjf 
Siayah, Syarofis; \& Setiawan, Adib Rifqi. (2020, April 13). A Brief Explanation of Science Education. EdArXiv. DOI: https://doi.org/10.35542/osf.io/2evn3

Siayah, Syarofis; \& Setiawan, Adib Rifqi. (2020, April 13). A Brief Explanation of Science Education. Thesis Commons. DOI: https://doi.org/10.31237/osf.io/wkvsn

Setiawan, Adib Rifai; \& Ilmiyah, Surotul. (2020, April 13). Multiple Intelligences Based on Neuroscience. Thesis Commons. DOI: https://doi.org/10.31237/osf.io/e9fyu

Setiawan, Adib Rifqi; \& Ilmiyah, Surotul. (2020, April 13). Kecerdasan Majemuk Berdasarkan Neurosains. EdArXiv. DOI: https://doi.org/10.35542/osf.io/rj2fe

Setiawan, Adib Rifqi. (2020, April 9). Islamic Education in Southeast Asia. EdArXiv. DOI: https://doi.org/10.35542/osf.io/dnjqv

Ilmiyah, Surotul; \& Setiawan, Adib Rifqi. (2020, April 7). Students' Worksheet for Distance Learning Based on Scientific Literacy in the Topic Coronavirus Disease 2019 (COVID-19). Thesis Commons. DOI: https://doi.org/10.31237/osf.io/fpg4j

Ilmiyah, Surotul; \& Setiawan, Adib Rifqi. (2020, April 7). Students' Worksheet for Distance Learning Based on Scientific Literacy in the Topic Coronavirus Disease 2019 (COVID-19). EdArXiv. DOI: https://doi.org/10.35542/osf.io/wyz5v

Setiawan, Adib Rifqi; \& Ilmiyah, Surotul. (2020, April 7). Lembar Kegiatan Siswa untuk Pembelajaran Jarak Jauh Berdasarkan Literasi Saintifik pada Topik Penyakit Coronavirus 2019 (COVID-19). EdArXiv. DOI: https://doi.org/10.35542/osf.io/h4632

Setiawan, Adib Rifqi. (2020, April 2). Desain Pembelajaran untuk Membimbing Siswa Sekolah Dasar dalam Memperoleh Literasi Saintifik. EdArXiv. DOI: https://doi.org/10.35542/osf.io/u59f8

Velasufah, Whasfi; \& Setiawan, Adib Rifqi. (2020, April 13). Nilai Pesantren Sebagai Dasar Pendidikan Karakter. Thesis Commons. DOI: https://doi.org/10.31237/osf.io/hq6kz

Setiawan, Adib Rifqi. (2020, April 9). Islamic Education in Southeast Asia. Thesis Commons. DOI: https://doi.org/10.31237/osf.io/e794d

Setiawan, Adib Rifqi. (2020, April 2). What is the Best Way to Analyze Pre-Post Data?. EdArXiv. DOI: https://doi.org/10.35542/osf.io/h4e6q

Setiawan, Adib Rifqi. (2020, April 4). Grace Natalie Louisa. SocArXiv. DOI: https://doi.org/10.31235/osf.io/zwf6g

Setiawan, Adib Rifqi. (2020, April 3). Sharifah Halimah Alaydrus : a female preachers for our time. SocArXiv. DOI: https://doi.org/10.31235/osf.io/zb8qe

Setiawan, Adib Rifqi. (2020, April 1). Syarifah Halimah Alaydrus. Thesis Commons. DOI: https://doi.org/10.31237/osf.io/xbmcs

Setiawan, Adib Rifqi. (2020, April 13). Commodification of the Sexuality in Kim Kardashian's Instagram Posts. Thesis Commons. URL: https://thesiscommons.org/mf7nw/

Setiawan, Adib Rifqi. (2020, April 5). The Arrogant One. Thesis Commons. DOI: https://doi.org/10.31237/osf.io/8nmku

Setiawan, Adib Rifqi. (2020, April 4). Grace Natalie Louisa. Thesis Commons. DOI: https://doi.org/10.31237/osf.io/u3mxv

Setiawan, Adib Rifqi. (2020, April 2). JUPE My Uncut Story. Open Science Framework (OSF). DOI: https://doi.org/10.31219/osf.io/qdxga

Setiawan, Adib Rifqi. (2020, April 1). Sharifah Halimah Alaydrus. Thesis Commons. DOI: https://doi.org/10.31237/osf.io/fp79c

Setiawan, Adib Rifqi. (2020, April 13). مبادئ اللغة العربية. Thesis Commons. DOI: https://doi.org/10.31237/osf.io/2gvjf

Siayah, Syarofis; \& Setiawan, Adib Rifqi. (2020, April 13). A Brief Explanation of Science Education. EdArXiv. DOI: https://doi.org/10.35542/osf.io/2evn3

Siayah, Syarofis; \& Setiawan, Adib Rifqi. (2020, April 13). A Brief Explanation of Science Education. Thesis Commons. DOI: https://doi.org/10.31237/osf.io/wkvsn 
Setiawan, Adib Rifqi; \& Ilmiyah, Surotul. (2020, April 13). Multiple Intelligences Based on Neuroscience. Thesis Commons. DOI: https://doi.org/10.31237/osf.io/e9fyu

Setiawan, Adib Rifqi; \& Ilmiyah, Surotul. (2020, April 13). Kecerdasan Majemuk Berdasarkan Neurosains. EdArXiv. DOI: https://doi.org/10.35542/osf.io/rj2fe

Setiawan, Adib Rifqi. (2020, April 9). Islamic Education in Southeast Asia. EdArXiv. DOI: https://doi.org/10.35542/osf.io/dnjqv

Ilmiyah, Surotul; \& Setiawan, Adib Rifqi. (2020, April 7). Students' Worksheet for Distance Learning Based on Scientific Literacy in the Topic Coronavirus Disease 2019 (COVID-19). Thesis Commons. DOI: https://doi.org/10.31237/osf.io/fpg4j

Ilmiyah, Surotul; \& Setiawan, Adib Rifqi. (2020, April 7). Students' Worksheet for Distance Learning Based on Scientific Literacy in the Topic Coronavirus Disease 2019 (COVID-19). EdArXiv. DOI: https://doi.org/10.35542/osf.io/wyz5v

Setiawan, Adib Rifqi; \& Ilmiyah, Surotul. (2020, April 7). Lembar Kegiatan Siswa untuk Pembelajaran Jarak Jauh Berdasarkan Literasi Saintifik pada Topik Penyakit Coronavirus 2019 (COVID-19). EdArXiv. DOI: https://doi.org/10.35542/osf.io/h4632

Setiawan, Adib Rifqi. (2020, April 2). Desain Pembelajaran untuk Membimbing Siswa Sekolah Dasar dalam Memperoleh Literasi Saintifik. EdArXiv. DOI: https://doi.org/10.35542/osf.io/u59f8

Velasufah, Whasfi; \& Setiawan, Adib Rifqi. (2020, April 13). Nilai Pesantren Sebagai Dasar Pendidikan Karakter. Thesis Commons. DOI: https://doi.org/10.31237/osf.io/hq6kz

Setiawan, Adib Rifqi. (2020, April 9). Islamic Education in Southeast Asia. Thesis Commons. DOI: https://doi.org/10.31237/osf.io/e794d

Setiawan, Adib Rifqi. (2020, April 2). What is the Best Way to Analyze Pre-Post Data?. EdArXiv. DOI: https://doi.org/10.35542/osf.io/h4e6q

Setiawan, Adib Rifqi. (2020, April 4). Grace Natalie Louisa. SocArXiv. DOI: https://doi.org/10.31235/osf.io/zwf6g

Setiawan, Adib Rifqi. (2020, April 3). Sharifah Halimah Alaydrus : a female preachers for our time. SocArXiv. DOI: https://doi.org/10.31235/osf.io/zb8qe

Setiawan, Adib Rifqi. (2020, April 1). Syarifah Halimah Alaydrus. Thesis Commons. DOI: https://doi.org/10.31237/osf.io/xbmcs

Setiawan, Adib Rifqi. (2020, April 13). Commodification of the Sexuality in Kim Kardashian's Instagram Posts. Thesis Commons. URL: https://thesiscommons.org/mf7nw/

Setiawan, Adib Rifqi. (2020, April 5). The Arrogant One. Thesis Commons. DOI: https://doi.org/10.31237/osf.io/8nmku

Setiawan, Adib Rifqi. (2020, April 4). Grace Natalie Louisa. Thesis Commons. DOI: https://doi.org/10.31237/osf.io/u3mxv

Setiawan, Adib Rifqi. (2020, April 2). JUPE My Uncut Story. Open Science Framework (OSF). DOI: https://doi.org/10.31219/osf.io/qdxga

Setiawan, Adib Rifqi. (2020, April 1). Sharifah Halimah Alaydrus. Thesis Commons. DOI: https://doi.org/10.31237/osf.io/fp79c

Setiawan, Adib Rifqi. (2020, April 13). مبادئ اللغة العربية. Thesis Commons. DOI: https://doi.org/10.31237/osf.io/2gvjf

Siayah, Syarofis; \& Setiawan, Adib Rifqi. (2020, April 13). A Brief Explanation of Science Education. EdArXiv. DOI: https://doi.org/10.35542/osf.io/2evn3

Siayah, Syarofis; \& Setiawan, Adib Rifqi. (2020, April 13). A Brief Explanation of Science Education. Thesis Commons. DOI: https://doi.org/10.31237/osf.io/wkvsn

Setiawan, Adib Rifqi; \& Ilmiyah, Surotul. (2020, April 13). Multiple Intelligences Based on Neuroscience. Thesis Commons. DOI: https://doi.org/10.31237/osf.io/e9fyu

Setiawan, Adib Rifqi; \& Ilmiyah, Surotul. (2020, April 13). Kecerdasan Majemuk Berdasarkan Neurosains. EdArXiv. DOI: https://doi.org/10.35542/osf.io/rj2fe 
Setiawan, Adib Rifqi. (2020, April 9). Islamic Education in Southeast Asia. EdArXiv. DOI: https://doi.org/10.35542/osf.io/dnjqv

Ilmiyah, Surotul; \& Setiawan, Adib Rifqi. (2020, April 7). Students' Worksheet for Distance Learning Based on Scientific Literacy in the Topic Coronavirus Disease 2019 (COVID-19). Thesis Commons. DOI: https://doi.org/10.31237/osf.io/fpg4j

Ilmiyah, Surotul; \& Setiawan, Adib Rifqi. (2020, April 7). Students' Worksheet for Distance Learning Based on Scientific Literacy in the Topic Coronavirus Disease 2019 (COVID-19). EdArXiv. DOI: https://doi.org/10.35542/osf.io/wyz5v

Setiawan, Adib Rifqi; \& Ilmiyah, Surotul. (2020, April 7). Lembar Kegiatan Siswa untuk Pembelajaran Jarak Jauh Berdasarkan Literasi Saintifik pada Topik Penyakit Coronavirus 2019 (COVID-19). EdArXiv. DOI: https://doi.org/10.35542/osf.io/h4632

Setiawan, Adib Rifqi. (2020, April 2). Desain Pembelajaran untuk Membimbing Siswa Sekolah Dasar dalam Memperoleh Literasi Saintifik. EdArXiv. DOI: https://doi.org/10.35542/osf.io/u59f8

Velasufah, Whasfi; \& Setiawan, Adib Rifqi. (2020, April 13). Nilai Pesantren Sebagai Dasar Pendidikan Karakter. Thesis Commons. DOI: https://doi.org/10.31237/osf.io/hq6kz

Setiawan, Adib Rifqi. (2020, April 9). Islamic Education in Southeast Asia. Thesis Commons. DOI: https://doi.org/10.31237/osf.io/e794d

Setiawan, Adib Rifqi. (2020, April 2). What is the Best Way to Analyze Pre-Post Data?. EdArXiv. DOI: https://doi.org/10.35542/osf.io/h4e6q

Setiawan, Adib Rifqi. (2020, April 4). Grace Natalie Louisa. SocArXiv. DOI: https://doi.org/10.31235/osf.io/zwf6g

Setiawan, Adib Rifqi. (2020, April 3). Sharifah Halimah Alaydrus : a female preachers for our time. SocArXiv. DOI: https://doi.org/10.31235/osf.io/zb8qe

Setiawan, Adib Rifqi. (2020, April 1). Syarifah Halimah Alaydrus. Thesis Commons. DOI: https://doi.org/10.31237/osf.io/xbmcs

Setiawan, Adib Rifqi. (2020, April 13). Commodification of the Sexuality in Kim Kardashian's Instagram Posts. Thesis Commons. URL: https://thesiscommons.org/mf7nw/

Setiawan, Adib Rifqi. (2020, April 5). The Arrogant One. Thesis Commons. DOI: https://doi.org/10.31237/osf.io/8nmku

Setiawan, Adib Rifqi. (2020, April 4). Grace Natalie Louisa. Thesis Commons. DOI: https://doi.org/10.31237/osf.io/u3mxv

Setiawan, Adib Rifqi. (2020, April 2). JUPE My Uncut Story. Open Science Framework (OSF). DOI: https://doi.org/10.31219/osf.io/qdxga

Setiawan, Adib Rifqi. (2020, April 1). Sharifah Halimah Alaydrus. Thesis Commons. DOI: https://doi.org/10.31237/osf.io/fp79c

Setiawan, Adib Rifqi. (2020, April 13). مبادئ اللغة العربية. Thesis Commons. DOI: https://doi.org/10.31237/osf.io/2gvjf

Siayah, Syarofis; \& Setiawan, Adib Rifqi. (2020, April 13). A Brief Explanation of Science Education. EdArXiv. DOI: https://doi.org/10.35542/osf.io/2evn3

Siayah, Syarofis; \& Setiawan, Adib Rifqi. (2020, April 13). A Brief Explanation of Science Education. Thesis Commons. DOI: https://doi.org/10.31237/osf.io/wkvsn

Setiawan, Adib Rifai; \& Ilmiyah, Surotul. (2020, April 13). Multiple Intelligences Based on Neuroscience. Thesis Commons. DOI: https://doi.org/10.31237/osf.io/e9fyu

Setiawan, Adib Rifqi; \& Ilmiyah, Surotul. (2020, April 13). Kecerdasan Majemuk Berdasarkan Neurosains. EdArXiv. DOI: https://doi.org/10.35542/osf.io/rj2fe

Setiawan, Adib Rifqi. (2020, April 9). Islamic Education in Southeast Asia. EdArXiv. DOI: https://doi.org/10.35542/osf.io/dnjqv 
Ilmiyah, Surotul; \& Setiawan, Adib Rifqi. (2020, April 7). Students' Worksheet for Distance Learning Based on Scientific Literacy in the Topic Coronavirus Disease 2019 (COVID-19). Thesis Commons. DOI: https://doi.org/10.31237/osf.io/fpg4j

Ilmiyah, Surotul; \& Setiawan, Adib Rifqi. (2020, April 7). Students' Worksheet for Distance Learning Based on Scientific Literacy in the Topic Coronavirus Disease 2019 (COVID-19). EdArXiv. DOI: https://doi.org/10.35542/osf.io/wyz5v

Setiawan, Adib Rifqi; \& Ilmiyah, Surotul. (2020, April 7). Lembar Kegiatan Siswa untuk Pembelajaran Jarak Jauh Berdasarkan Literasi Saintifik pada Topik Penyakit Coronavirus 2019 (COVID-19). EdArXiv. DOI: https://doi.org/10.35542/osf.io/h4632

Setiawan, Adib Rifqi. (2020, April 2). Desain Pembelajaran untuk Membimbing Siswa Sekolah Dasar dalam Memperoleh Literasi Saintifik. EdArXiv. DOI: https://doi.org/10.35542/osf.io/u59f8

Velasufah, Whasfi; \& Setiawan, Adib Rifqi. (2020, April 13). Nilai Pesantren Sebagai Dasar Pendidikan Karakter. Thesis Commons. DOI: https://doi.org/10.31237/osf.io/hq6kz

Setiawan, Adib Rifqi. (2020, April 9). Islamic Education in Southeast Asia. Thesis Commons. DOI: https://doi.org/10.31237/osf.io/e794d

Setiawan, Adib Rifqi. (2020, April 2). What is the Best Way to Analyze Pre-Post Data?. EdArXiv. DOI: https://doi.org/10.35542/osf.io/h4e6q

Setiawan, Adib Rifqi. (2020, April 4). Grace Natalie Louisa. SocArXiv. DOI: https://doi.org/10.31235/osf.io/zwf6g

Setiawan, Adib Rifqi. (2020, April 3). Sharifah Halimah Alaydrus : a female preachers for our time. SocArXiv. DOI: https://doi.org/10.31235/osf.io/zb8qe

Setiawan, Adib Rifqi. (2020, April 1). Syarifah Halimah Alaydrus. Thesis Commons. DOI: https://doi.org/10.31237/osf.io/xbmcs

Setiawan, Adib Rifqi. (2020, April 13). Commodification of the Sexuality in Kim Kardashian's Instagram Posts. Thesis Commons. URL: https://thesiscommons.org/mf7nw/

Setiawan, Adib Rifqi. (2020, April 5). The Arrogant One. Thesis Commons. DOI: https://doi.org/10.31237/osf.io/8nmku

Setiawan, Adib Rifqi. (2020, April 4). Grace Natalie Louisa. Thesis Commons. DOI: https://doi.org/10.31237/osf.io/u3mxv

Setiawan, Adib Rifqi. (2020, April 2). JUPE My Uncut Story. Open Science Framework (OSF). DOI: https://doi.org/10.31219/osf.io/qdxga

Setiawan, Adib Rifqi. (2020, April 1). Sharifah Halimah Alaydrus. Thesis Commons. DOI: https://doi.org/10.31237/osf.io/fp79c

Setiawan, Adib Rifqi. (2020, April 13). مبادئ اللغة العربية. Thesis Commons. DOI: https://doi.org/10.31237/osf.io/2gvjf

Siayah, Syarofis; \& Setiawan, Adib Rifqi. (2020, April 13). A Brief Explanation of Science Education. EdArXiv. DOI: https://doi.org/10.35542/osf.io/2evn3

Siayah, Syarofis; \& Setiawan, Adib Rifqi. (2020, April 13). A Brief Explanation of Science Education. Thesis Commons. DOI: https://doi.org/10.31237/osf.io/wkvsn

Setiawan, Adib Rifqi; \& Ilmiyah, Surotul. (2020, April 13). Multiple Intelligences Based on Neuroscience. Thesis Commons. DOI: https://doi.org/10.31237/osf.io/e9fyu

Setiawan, Adib Rifqi; \& Ilmiyah, Surotul. (2020, April 13). Kecerdasan Majemuk Berdasarkan Neurosains. EdArXiv. DOI: https://doi.org/10.35542/osf.io/rj2fe

Setiawan, Adib Rifqi. (2020, April 9). Islamic Education in Southeast Asia. EdArXiv. DOI: https://doi.org/10.35542/osf.io/dnjqv

Ilmiyah, Surotul; \& Setiawan, Adib Rifqi. (2020, April 7). Students' Worksheet for Distance Learning Based on Scientific Literacy in the Topic Coronavirus Disease 2019 (COVID-19). Thesis Commons. DOI: https://doi.org/10.31237/osf.io/fpg4j 
Ilmiyah, Surotul; \& Setiawan, Adib Rifqi. (2020, April 7). Students' Worksheet for Distance Learning Based on Scientific Literacy in the Topic Coronavirus Disease 2019 (COVID-19). EdArXiv. DOI: https://doi.org/10.35542/osf.io/wyz5v

Setiawan, Adib Rifqi; \& Ilmiyah, Surotul. (2020, April 7). Lembar Kegiatan Siswa untuk Pembelajaran Jarak Jauh Berdasarkan Literasi Saintifik pada Topik Penyakit Coronavirus 2019 (COVID-19). EdArXiv. DOI: https://doi.org/10.35542/osf.io/h4632

Setiawan, Adib Rifqi. (2020, April 2). Desain Pembelajaran untuk Membimbing Siswa Sekolah Dasar dalam Memperoleh Literasi Saintifik. EdArXiv. DOI: https://doi.org/10.35542/osf.io/u59f8

Velasufah, Whasfi; \& Setiawan, Adib Rifqi. (2020, April 13). Nilai Pesantren Sebagai Dasar Pendidikan Karakter. Thesis Commons. DOI: https://doi.org/10.31237/osf.io/hq6kz

Setiawan, Adib Rifqi. (2020, April 9). Islamic Education in Southeast Asia. Thesis Commons. DOI: https://doi.org/10.31237/osf.io/e794d

Setiawan, Adib Rifqi. (2020, April 2). What is the Best Way to Analyze Pre-Post Data?. EdArXiv. DOI: https://doi.org/10.35542/osf.io/h4e6q

Setiawan, Adib Rifqi. (2020, April 4). Grace Natalie Louisa. SocArXiv. DOI: https://doi.org/10.31235/osf.io/zwf6g

Setiawan, Adib Rifqi. (2020, April 3). Sharifah Halimah Alaydrus : a female preachers for our time. SocArXiv. DOI: https://doi.org/10.31235/osf.io/zb8qe

Setiawan, Adib Rifqi. (2020, April 1). Syarifah Halimah Alaydrus. Thesis Commons. DOI: https://doi.org/10.31237/osf.io/xbmcs

Setiawan, Adib Rifqi. (2020, April 13). Commodification of the Sexuality in Kim Kardashian's Instagram Posts. Thesis Commons. URL: https://thesiscommons.org/mf7nw/

Setiawan, Adib Rifqi. (2020, April 5). The Arrogant One. Thesis Commons. DOI: https://doi.org/10.31237/osf.io/8nmku

Setiawan, Adib Rifqi. (2020, April 4). Grace Natalie Louisa. Thesis Commons. DOI: https://doi.org/10.31237/osf.io/u3mxv

Setiawan, Adib Rifqi. (2020, April 2). JUPE My Uncut Story. Open Science Framework (OSF). DOI: https://doi.org/10.31219/osf.io/qdxga

Setiawan, Adib Rifqi. (2020, April 1). Sharifah Halimah Alaydrus. Thesis Commons. DOI: https://doi.org/10.31237/osf.io/fp79c

Setiawan, Adib Rifqi. (2020, April 13). مبادئ اللغة العربية. Thesis Commons. DOI: https://doi.org/10.31237/osf.io/2gvjf 